\title{
KEMAMPUAN MAHASISWA PENDIDIKAN MATEMATIKA UNIVERSITAS PGRI ADI BUANA SURABAYA DALAM MEMECAHKAN SOAL MATEMATIKA DISKRIT
}

\author{
Lydia Lia Prayitno \\ Dosen Pendidikan Matematika - FKIP - Universitas PGRI Adi Buana Surabaya \\ lydia.liaprayitno5@gmail.com
}

\begin{abstract}
Abstrak
LPTK merupakan salah satu penghasil tenaga kependidikan yang berkualitas. Salah satu komponen yang penting adalah kemampuan mahasiswa calon guru dalam memecahkan masalah, khususnya pada mata kuliah matematika diskrit. Penelitian ini merupakan penelitian kualitatif, yang bertujuan untuk menggambarkan kemampuan mahasiswa dalam memecahkan masalah matematika formal dan masalah kontekstual. Hasil penelitian ini adalah : 1) mahasiswa kemampuan tinggi dapat menyelesaikan semua masalah tetapi dia membuat kesalahan untuk kesimpulan sehingga kemampuan memecahkan masalah berada pada kategori baik, 2) mahasiswa kemampuan sedang dapat menyelesaikan semua masalah dengan sempurna sehingga kemampuan memecahkan masalah berada pada kategori sangat baik, dan 3) mahasiswa kemampuan rendah tidak dapat memecahkan masalah formal dan menyelesaikan masalah kontekstual menggunakan metode Polya.
\end{abstract}

Kata kunci: kemampuan, memecahkan masalah, matematika diskrit

\section{Pendahuluan}

Pendidikan merupakan salah satu topik hangat yang selalu menjadi pembicaraan di berbagai kalangan masyarakat. Tidak hanya pendidikan formal saja melainkan pendidikan non formal juga selalu menjadi perbincangan banyak pihak. Masing-masing jenis pendidikan mempunyai kurikulum yang berbeda sesuai dengan kompetensi yang ingin dikuasai lulusannya dan jenjang pendidikannya. Selain itu, penyusunan kurikulum yang digunakan untuk masingmasing pendidikan dan jenjangnya juga disesuaikan dengan kebutuhan stakeholder yang akan menggunakan lulusan tersebut. Hal ini juga yang perlu diperhatikan oleh pendidikan formal seperti perguruan tinggi khususnya Lembaga Pendidikan Tenaga Kependidikan (LPTK). Jika tidak sesuai dengan kebutuhan stakeholder maka lulusan yang dihasilkan oleh sebuah LPTK tidak akan terserap dengan baik pada dunia pendidikan.
Jika hal ini terjadi menunjukkan bahwa tujuan pendidikan nasional yang telah dicanangkan tidak berjalan dengan baik.

Berdasarkan kurikulum yang telah diterapkan di Indonesia, salah satu materi yang diajarkan dari tingkat dasar sampai dengan tingkat tinggi adalah matematika. Matematika diajarkan mulai tingkat dasar sampai tingkat tinggi, oleh karena itu diperlukan sebuah LPTK yang mampu menghasilkan pendidik yang menguasai cara mengajarkan matematika dengan baik kepada siswanya.

Soedjadi (1992:20) mengatakan bahwa matematika sebagai salah satu ilmu dasar, memegang peranan penting dalam mempercepat penguasaan ilmu dan teknologi. Hal itu dikarenakan matematika merupakan sarana berpikir untuk menumbuhkembangkan cara berpikir logis, sistematis, dan kritis. Sampai pada batas tertentu, matematika perlu dikuasai oleh segenap warga negara, baik yang terkait dengan penerapannya maupun dengan 
pola pikirnya. Selanjutnya Hudoyo (1994:2) mengatakan bahwa penguasaan ilmu pengetahuan dan teknologi harus didasari oleh penguasaan matematika, karena penguasaan matematika merupakan kunci utama dalam menguasai ilmu pengetahuan.

Sebelum seorang pendidik lulus dari sebuah LPTK, calon pendidik tersebut harus mengikuti kegiatan pendidikan di LPTK selama \pm 4 tahun untuk menguasai kompetensinya. Kompetensi yang dimaksud adalah menjadi seorang pendidik yang berkompeten dan profesional di bidang pendidikan matematika. Pendidik yang berkompeten dan profesional di bidang pendidikan matematika akan dihasilkan oleh sebuah LPTK yang kompeten dan profesional juga. Selama menempuh pendidikan di LPTK, calon pendidik dikenal tersebut dikenal sebagai mahasiswa.

Tugas sebuah LPTK untuk menghasilkan calon pendidik yang profesional bukanlah hal yang mudah. Hal ini dikarenakan terdapat beberapa hal penting harus ditanamkan dalam diri mahasiswa sebelum mahasiwa tersebut terjun ke dunia sekolah yang real. Menurut Steiner dan Fresenborg (dalam Marpaung, 1993:2) salah satu tugas pokok pendidikan yang penting adalah menjelaskan proses berpikir siswa (dalam penelitian ini mahasiswa) dalam mempelajari matematika dengan tujuan memperbaiki pengajaran matematika di sekolah. Proses berfikir mahasiswa dapat diketahui dari bagaimana kemampuan mahasiswa tersebut dalam menyelesaikan sebuah permasalahan (soal) matematika.

Ketika kemampuan mahasiswa dalam memecahkan masalah (soal) diperhatikan diharapkan sebuah LPTK akan mencetak tenaga pendidik yang profesional, khususnya pendidikan matematika. Akan tetapi pada kenyataannya, proses perkuliahan yang dilakukan termasuk evaluasinya masih berfokus pada produknya saja. Sehingga masih kurang memperhatikan kemampuan mahasiswa dalam memecahkan masalah matematika. Selain itu, salah satu tugas pokok pendidik adalah harus memperhatikan kesulitan mahasiswanya dalam mempelajari materi yang diajarkan. Dengan memperhatikan kemampuan mahasiswa dan mengetahui kesulitan siswa, pendidik dapat memperbaiki proses pembelajaran yang dilakukannya selama ini. Kemampuan mahasiswa dalam memecahkan masalah matematika merupakan suatu hal yang penting.

Hal ini dikarenakan ketika seorang mahasiswa diajarkan mengetahui kemampuannya dalam memecahkan masalah diharapkan juga ketika mahasiswa tersebut menjadi seorang pendidik juga memperhatikan kemampuan memecahkan masalah siswanya. Harapan selanjutnya adalah materi pembelajaran yang disampaikan pada pembelajaran matematika di sekolah dapat tersampaikan dengan baik kepada siswa sehingga kesulitan-kesulitan yang dialami siswa secara bertahap dapat segera ditangani.

Menurut Suherman (2008) matematika merupakan salah satu materi yang bersifat abstrak, dalam hal ini tidak hanya siswa melainkan juga mahasiswa. Sehingga untuk menanam-kan konsep matematika yang bersifat abstrak diperlukan cara yang berbedabeda untuk setiap jenjangnya. Banyak hal yang dapat dilakukan pendidik untuk mengatasinya, misalnya melalui penggunaan media ataupun alat peraga, pemahaman konsep yang mendalam, yang dilanjutkan dengan latihan untuk memantapkan konsep yang telah dipelajarinya.

Dalam memantapkan konsep yang telah dipelajari dapat dilakukan dengan pemecahan masalah matematika. Pada prinsipnya masalah matematika terdiri atas masalah matematika 
formal dan masalah matematika kontekstual. Sudah menjadi rahasia umum bahwa masalah matematika kontekstual baik digunakan untuk semua jenjang pendidikan dan semua kegiatan pembelajaran. Hal ini diperkuat pendapat Soedjadi (2007:43) yang mengungkapkan bahwa "masalah matematika kontekstual baik digunakan pada awal suatu topik pembelajaran yang baru". Tujuannya adalah agar mahasiswa dapat lebih menanamkan konsep baru yang sedang dipelajarinya melalui lingkungan yang telah dikenalnya.

Pada prinsipnya masalah matematika kontekstual dapat digunakan di tengah ataupun pada akhir pembelajaran. Untuk masalah kontekstual yang digunakan di tengah pembelajaran bertujuan untuk memantapkan konsep yang telah dibangunnya, sedangkan masalah kontekstual yang digunakan di akhir pembelajaran bertujuan untuk menerapkan pengetahuan yang telah dibangunnya. Dari tujuan yang telah diuraikan di atas, masalah matematika kontekstual sebaiknya dipertimbangkan untuk dihadirkan pada kegiatan pembelajaran.

Dalam penelitian ini, kemampuan mahasiswa dalam memecahkan masalah akan ditinjau dari bagaimana cara mahasiswa tersebut memecahkan masalah matematika formal dan masalah matematika kontekstual. Menurut Kirkley (dalam Anggo, 2009) pemecahan masalah merupakan perwujudan dari suatu aktivitas mental yang terdiri dari bermacam-macam keterampilan dan tindakan kognitif dan bertujuan untuk mendapatkan solusi yang benar dari masalah. Karena pada dasarnya pemecahan masalah melibatkan tindakan kognitif, maka berimplikasi pada kemampuan setiap mahasiswa tidak akan sama.

Kemampuan mahasiswa dalam memecahkan masalah dipengaruhi oleh tingkat kemampuan mahasiswa, yaitu mahasiswa yang berkemampuan tinggi, sedang dan rendah. Masing-masing tingkat kemampuan mahasiswa akan mempunyai karakteristik yang berbeda antara satu dengan yang lainnya. Dalam penelitian ini kemampuan mahasiswa dalam memecahkan masalah dilakukan dengan memberikan soal pemecahan masalah matematika formal, masalah matematika kontekstual. Harapannya adalah mahasiswa dapat menyelesaikannya sesuai dengan langkah-langkah pemecahan masalah yang dirumuskan oleh Polya.

Berdasarkan pengalaman peneliti sebagai pengampu mata kuliah Matematika Diskrit di Universitas PGRI Adi Buana Surabaya, mahasiswa masih mengalami kesulitan dalam menyelesaikan masalah matematika formal. Akibatnya mahasiswa tidak mampu menyelesaikan masalah matematika kontekstual yang diberikan. Hal ini disebabkan karena mahasiswa telah terbiasa dengan mengoperasikan langsung tanpa memperhatikan prosesnya. Tentu saja akan menimbulkan kebingungan bagi mahasiswa dikarenakan konsep matematika yang bersifat deduktif. Jika mempelajari konsep B yang didasarkan pada konsep A, maka terlebih dahulu menguasai konsep A. Tanpa memahami konsep A, tidak mungkin mahasiswa menguasai konsep B.

Mata kuliah Matematika Diskrit merupakan salah satu mata kuliah di semester genap tahun akademik 2013/2014. Mata kuliah ini diajarkan pada mahasiswa semester enam dan telah menempuh mata kuliah prasyarat yaitu pengantar dasar matematika dan teori bilangan.

Seperti yang telah dikemukakan di atas, dapat diketahui pentingnya mengetahui kemampuan mahasiswa dalam memecahkan masalah (soal) matematika formal dan masalah matematika kontekstual. Berkaitan dengan hal itu, peneliti memandang perlu untuk 
mengetahui kemampuan mahasiswa matematika dalam menyelesaikan masalah matematika.

Berdasarkan uraian latar belakang di atas dapat ditentukan pertanyaan dalam penelitian ini yaitu "Bagaimana kemampuan mahasiswa pendidikan matematika Universitas PGRI Adi Buana Surabaya dalam memecahkan soal matematika diskrit?". Dalam penelitian ini akan ditinjau dari kemampuan mahasiswa dengan kemampuan tinggi, sedang dan rendah dalam menyelesaikan masalah matematika formal dan kontekstual.

\section{Metode Penelitian}

Penelitian ini bertujuan mengungkapkan kemampuan mahasiswa Pendidikan Matematika dalam menyelesaikan masalah matematika formal kontekstual. Untuk menjawab pertanyaan penelitian tersebut, pendekatan yang digunakan adalah pendekatan kualitatif. Hal ini dikarenakan penelitian ini lebih mengutamakan kemampuan mahasiswa dalam menyelesaikan masalah formal dan kontekstual. Sedangkan penelitian ini termasuk jenis penelitian deskriptif eksploratif. Hal ini dikarenakan penelitian bermaksud untuk menggali, memaparkan atau mendeskripsikan kemampuan mahasiswa dalam menyelesaikan masalah matematika kontekstual dan masalah matematika formal. Selain itu pendeskripsian ini akan ditinjau dari perbedaan kemampuan yang didasarkan pada IPK dan Tes Kemampuan Awal (TKA).

Subjek penelitian adalah mahasiswa dengan IPK tinggi dan TKA tinggi sebagai subjek I (S1), mahasiswa dengan IPK sedang dan TKA sedang sebagai subjek II (S2), dan mahasiswa dengan IPK rendah dan TKA rendah sebagai subjek III (S3). Dalam penelitian ini, mahasiswa yang tidak memenuhi kriteria subjek penelitian yang ditetapkan tidak digunakan sebagai subjek penelitian. Sehingga dalam penelitian ini hanya ada tiga subjek penelitian saja.

Dalam penelitian ini, metode penelitian yang digunakan antara lain metode tes dan metode wawancara. Sedangkan instrumen pengumpulan data yang digunakan adalah soal tes, peneliti sebagai instrumen utama serta instrumen pendukung.

Proses kegiatan analisis data yang dilakukan dalam penelitian ini meliputi reduksi data (data reduction), penyajian data (data display), menginterpretasi data, penarikan kesimpulan, validasi data.

\section{Hasil Penelitian}

Penelitian ini dilaksanakan pada semester genap tahun akademik 2013/2014 pada mata kuliah Matematika Diskrit. Pada semester genap ini, mahasiswa yang memprogram mata kuliah Matematika Diskrit adalah program studi Pendidikan Matematika angkatan 2010. Penelitian ini dilakukan pada saat Ujian Tengah Semester (UTS) semester genap tahun akademik 2013/2014.

Sebelum melakukan penelitian, peneliti terlebih dahulu melakukan validasi terhadap instrumen penelitian yang dilakukan oleh valiadator. Dari hasil validasi ahli, diperoleh hasil bahwa instrumen penelitian layak digunakan untuk penelitian.

Dalam proses analisis data selain peneliti melakukan wawancara secara mendalam kepada masing-masing subjek, peneliti juga memperhatikan hasil pekerjaan yang telah dilakukan oleh subjek.

\section{Subjek 1 (S1)}

Dalam memecahkan masalah matematika formal, S1 adalah subjek yang mempunyai kemampuan tinggi. S1 mampu memahami masalah yang diberikan pada soal nomor 1 . Setelah mampu memahami masalah formal yang diberikan, S1 mampu menentukan barisan awal yang akan disubtitusikan ke 
dalam persamaan. Jadi dapat dikatakan S1 mampu merencanakan penyelesaian untuk soal nomor 1. Selanjutnya, S1 mampu melaksanakan langkah-langkah sesuai dengan yang telah disebutkan pada tahap memahami masalah Selama proses wawancara berlangsung, S1 juga melakukan pengecekan hasil serta alasan-alasan dalam menggunakan formula yang ada (indikator 4.1 dan 4.2). Disini tampak S1 sangat berhati-hati dalam mengerjakan soal nomor 1 , karena sebelum menuliskan kesimpulan S1 meneliti kembali hasil pekerjaannya secara keseluruhan (indikator 4.3). Jadi dalam hal ini dikatakan S1 telah melakukan pengecekan terhadap hasil pekerjaannya secara keseluruhan. Secara keseluruhan, kemampuan S1 dalam memecahkan masalah matematika formal telah memenuhi indikator langkah-langkah pemecahan masalah. Sehingga dapat dikatakan S1 mampu memecahkan masalah matematika formal sesuai dengan indikator pemecahan masalah berdasarkan teori Polya.

Dalam memecahkan masalah matematika kontekstual, S1 mampu menyebutkan informasi yang terdapat pada soal (indikator 1.1), mampu menyebutkan pertanyaan yang diajukan dalam soal (indikator 1.2) serta mampu menentukan informasi yang relevan untuk menyelesaikan soal (indikator 1.3). Jadi dapat dikatakan S1 mampu memahami masalah yang diberikan pada soal nomor 2 . Setelah mampu memahami masalah kontekstual yang diberikan, S1 mampu menentukan bentuk umum dari fungsi pembangkit yang akan digunakan (indikator 2.1), mampu menentukan rumus yang digunakan untuk menyelesaikan masalah (indikator 2.2), mampu menghubungkan antara soal yang pernah diselesaikan dengan masalah yang sedang diselesaikan (indikator 2.3) serta mampu merubah informasi yang ada dalam soal menjadi diketahui sebelumnya (indikator
2.4). Jadi dapat dikatakan S1 mampu merencanakan penyelesaian soal nomor 2 . Setelah mampu merencanakan menyelesaikan masalah nomor 2, S1 mampu melaksanakan langkah-langkah sesuai dengan langkah penyelesaian masalah. Selama proses wawancara berlangsung, S1 juga melakukan pengecekan hasil serta alasan dalam menggunakan formula yang ada (indikator 4.1 dan 4.2). S1 juga memeriksa kembali hasil pekerjaannya setelah peneliti mengingatkan (indikator 4.3), karena S1 telah yakin dengan hasil pekerjaannya peneliti membacakan kembali soal nomor 2. Setelah dibacakan peneliti, S1 sadar kesalahan yang dilakukan. Pada intinya, S1 tidak melakukan kesalahan prosedur melainkan kurang teliti terhadap hasil akhirnya. Secara keseluruhan, kemampuan S1 dalam memecahkan masalah matematika kontekstual telah memenuhi indikator langkahlangkah pemecahan masalah. Sehingga dapat dikatakan S1 mampu memecahkan masalah matematika kontekstual sesuai dengan indikator pemecahan masalah menurut Polya. Tetapi kekurangannya adalah kekeliruan yang disebabkan kurang tepat melakukan pengecekan alasan dari soal yang ada.

\section{Subjek 2 (S2)}

Dalam memecahkan masalah matematika formal, S2 adalah subjek yang mempunyai kemampuan sedang. S2 mampu menyebutkan informasi yang terdapat pada soal (indikator 1.1), mampu menyebutkan pertanyaan yang diajukan dalam soal (indikator 1.2) serta mampu menentukan informasi yang relevan untuk menyelesaikan soal (indikator 1.3). Jadi dapat dikatakan, S2 mampu memahami masalah yang diberikan pada soal nomor 1 . Setelah mampu memahami masalah formal yang diberikan, S2 juga menggunakan barisan awal yang akan disubtitusikan ke dalam persamaan $\mathrm{P}(\mathrm{x})$ (indikator 2.1), mampu 
menentukan rumus yang digunakan untuk menyelesaikan masalah (indikator 2.2), mampu menghubungkan antara soal yang pernah diselesaikan sebelumnya dengan masalah yang sedang diselesaikan (indikator 2.3) serta mampu merubah informasi yang ada dalam soal menjadi diketahui sebelumnya (indikator 2.4). Jadi dapat dikatakan S2 mampu merencanakan penyelesaian soal nomor 1. Setelah mampu merencanakan untuk menyelesaikan masalah nomor 1, S2 mampu melaksanakan langkah-langkah sesuai dengan yang telah disebutkan pada tahap memahami masalah (indikator 3.1). Selama proses wawancara berlangsung, S2 juga melakukan pengecekan hasil (indikator 4.1). Setelah selesai menuliskan jawaban, S2 juga meneliti kembali hasil pekerjaannya secara keseluruhan (indikator 4.3). Barulah setelah itu S2 yakin dengan jawaban yang diberikan. Secara keseluruhan, kemampuan S2 dalam memecahkan masalah matematika formal telah memenuhi indikator langkah-langkah pemecahan masalah. Sehingga dapat dikatakan S2 mampu memecahkan masalah matematika formal sesuai dengan indikator pemecahan masalah.

Dalam memecahkan masalah matematika kontekstual, S2 mampu menyebutkan informasi yang terdapat pada soal (indikator 1.1), mampu menyebutkan pertanyaan yang diajukan dalam soal (indikator 1.2) serta mampu menentukan informasi yang relevan untuk menyelesaikan soal (indikator 1.3). Jadi dapat dikatakan S2 mampu memahami masalah yang diberikan pada soal nomor 2 . Setelah mampu memahami masalah kontekstual yang diberikan, S2 mampu menentukan bentuk umum dari fungsi pembangkit yang akan digunakan dalam memecahkan masalah matematika kontekstual (indikator 2.1), mampu menentukan rumus yang digunakan untuk menyelesaikan masalah (indikator 2.2), mampu membuat hubungan antara soal yang pernah diselesaikan dengan masalah yang sedang diselesaikan (indikator 2.3) serta mampu merubah informasi yang ada dalam soal menjadi diketahui sebelumnya (indikator 2.4). Jadi dapat dikatakan S2 mampu merencanakan penyelesaian soal nomor 2. Setelah merencanakan untuk menyelesaikan masalah nomor 2, S2 tampak lebih berhati-hati dalam mengerjakan. Hal ini terlihat beberapa kali S2 mengecek hasil pengerjaannya dan kesesuaian dengan alasan ataupun formula (indikator 4.1 dan 4.2). S2 juga meneliti kembali hasil pekerjaannya dengan mencoret-coret lembar soal untuk memastikan hasil pekerjaannya (indikator 4.3). Secara keseluruhan, kemampuan S2 dalam memecahkan masalah matematika kontekstual telah memenuhi indikator langkah-langkah pemecahan masalah. Sehingga dapat dikatakan S2 mampu memecahkan masalah matematika kontekstual sesuai dengan indikator pemecahan masalah menurut Polya.

\section{Subjek 3 (S3)}

Dalam memecahkan masalah matematika formal, S3 merupakan subjek dengan kemampuan rendah. S3 hanya mampu menyebutkan informasi yang terdapat dalam soal nomor 1 (indikator 1.1) serta menentukan informasi yang akan digunakan dalam menyelesaikan soal yaitu menentukan barisan (indikator 1.3). S3 tidak mampu menyebutkan apa yang ditanyakan dari soal, maka dapat dikatakan S3 tidak memahami masalah yang terdapat pada soal nomor 1. Sama halnya dengan subjek yang lain untuk membantu menentukan informasi awal digunakan barisan untuk membantu menyelesaikan masalah (indikator 2.1). Setelah itu, S3 mampu untuk menentukan rumus yang digunakan (indikator 2.2) dan mampu untuk menentukan hubunganhubungan yang digunakan dalam memecahkan masalah (indikator 2.3). S3 dapat 
merencanakan langkah penyelesaian masalah, akan tetapi mempunyai kendala untuk melangkah pada indikator 2.4. Selain itu, S3 tidak mampu menyelesaikan masalah sesuai dengan rencana yang telah dirancang sebelumnya serta tidak melakukan pengecekan untuk setiap jawaban yang diberikan. Meskipun dengan pertanyaan pancingan ternyata S3 tidak mampu untuk memecahkan masalah matematika formal. Secara keseluruhan, kemampuan S3 dalam memecahkan masalah formal tidak memenuhi indikator langkah-langkah pemecahan masalah. Sehingga dapat dikatakan S3 tidak mampu memecahkan masalah matematika formal sesuai dengan indikator pemecahan masalah menurut Polya.

Dalam memecahkan masalah matematika kontekstual, S3 mampu menyebutkan informasi yang terdapat pada soal nomor 2 (indikator 1.1), setelah itu S3 langsung menentukan informasi awal yang digunakan untuk menyelesaikan masalah (indikator 2.1). Disini tampak bahwa S3 kurang mampu memahami masalah yang diberikan pada soal nomor 2. S3 mampu menentukan informasi yang akan digunakan dan juga mampu untuk menentukan hubungan tentang masalah yang terkait dengan masalah (indikator 2.3) serta rumus yang akan digunakan untuk menyelesaikan masalah (indikator 2.2). S3 juga mampu dalam menentukan informasi yang tidak diketahui dengan mengubah dalam formula yang telah diketahui (indikator 2.4). Sebelumnya, S3 telah melakukan kesalahan karena pengecekan hasil yang kurang baik dilakukan. Sehingga untuk menyelesaikan soal nomor 2, S3 mengalami kesulitan sama halnya dengan ketika memecahkan masalah matematika formal. Secara keseluruh-an, kemampuan S3 dalam memecah-kan masalah matematika kontekstual tidak memenuhi indikator langkah-langkah pemecahan masalah. Sehingga dapat dikatakan S3 tidak mampu memecahkan masalah matematika kontekstual sesuai dengan indikator pemecahan masalah menurut Polya.

\section{Simpulan}

Berdasarkan hasil analisis yang telah dilakukan dapat disimpulkan kemampuan mahasiswa pendidikan matematika dalam memecahkan masalah (soal) matematika diskrit menurut Polya adalah sebagai berikut. 1) Subjek $S 1$ mampu memecahkan masalah matematika formal. S1 menyelesaikan secara runtut dalam memecahkan masalah formal, karena mampu menjelaskan dari awal menyelesaikan sampai mengarah pada kesimpulan. Sedangkan dalam me-mecahkan masalah matematika kontekstual, S1 menyelesaikan runtut dalam memecahkan masalah formal, karena mampu menjelaskan dari awal menyelesaikan sampai mengarah pada kesimpulan. S1 mempunyai kekurang-an yaitu melakukan kekeliruan yang disebabkan kurang tepat melakukan pengecekan alasan dari soal yang ada. 2) S2 dalam memecahkan masalah matematika formal dikerjakan secara runtut karena mampu menjelaskan dari awal menyelesaikan sampai mengarah pada kesimpulan. Sedangkan dalam menyelesaikan masalah kontekstual, S2 mampu menyelesaikan secara runtut seperti dalam memecahkan masalah formal, karena mampu menjelaskan dari awal menyelesaikan sampai mengarah pada kesimpulan. 3) S3 tidak mampu memecahkan masalah matematika formal karena kurang mampu menyelesaikan masalah sesuai dengan rencana yang telah direncanakan. Selain itu, langkah yang dilakukan oleh mahasiswa dengan kemampuan rendah tidak memenuhi indikator langkahlangkah pemecahan masalah menurut Polya. Sedangkan untuk masalah matematika kontekstual, S3 kurang runtut karena 
melakukan kesalahan dalam pengecekan hasil yang kurang baik. Mahasiswa dengan kemampuan rendah tidak memenuhi indikator langkah-langkah pemecahan masalah menurut Polya.

\section{Saran}

Adapun saran yang dapat diberikan peneliti terkait dengan hasil penelitian ini adalah sebagai berikut. 1) peneliti lain yang hendak menindaklanjuti hasil penelitian ini, disarankan untuk:

a. mencermati kembali indikator pemecahan masalah menurut Polya supaya mempermudah dalam melakukan analisis data,

b. menambahkan tipe berfikir subjek penelitian untuk dikaitkan dengan kemampuan pemecahan masalah

\section{Daftar Pustaka}

A'Echevarria, Anne \& Patience, Ian. 2011. Strategi Pengajaran Berfikir. Jakarta : Esensi, Erlangga Group.

Alisah, Evawati dan Dharmawan, Eko Prasetyo. 2007. Filsafat Dunia Matematika. Jakarta : Prestasi Pustaka Publisher.

Anggo, Mustamin. 2009. Metakognisi Mahasiswa Calon Guru Dalam Memecahkan Masalah Matematika Kontekstual. Makalah Seminar yang tidak dipublikasikan.

Dahar, Ratna Wilis. 2011. Teori-teori Belajar \& Pembelajaran. Jakarta : PT Erlangga.

De Corte, E. 2003. Intervention Research: A Tool for Bridging the Theory-Practice Gap in Mathematics Education. Procedings of the International Conference, The Mathematics
Education into the $21^{\text {th }}$ century project. Borno Czech Republic.

Gredler, Margaret E. 2011. Learning and Instruction. Jakarta : Kencana Prenada Media Group.

Hudojo, Herman. 1990. Strategi Belajar Mengajar. Malang: IKIP Malang.

Marpaung, Yansen. 1986. Proses Berpikir Siswa dalam Pembentukan Konsep Algoritma Matematik. Yogyakarta: Pidato Dies Natalis XXXI IKIP Sanata Dharma.

1987. Aspek-Aspek Kognitif yang Perlu Diketahui Guru-Guru Matematika Sebagai Bekal untuk dapat Membantu Siswa dengan Lebih Baik. Makalah Seminar Pendidikan Matematika. IKIP Sanata Dharma.

1993. Metode Kualitatif untuk Mempelajari Representasi Pengetahuan Matematika dalam Pikiran Siswa. FKIP Universitas Sanata Dharma.

Moleong, Lexi J. 2001. Metodologi Penelitian Kualitatif. Bandung: PT Remaja Rosdakarya.

Munir, Rinaldi. 2005. Matematika Diskrit. Jakarta: Penerbit Informatika.

Nelissen, 1997, Thinking Skill in Realistic Mathematics, Diakses tanggal 12 September 2006.

Polya, G. 1973. How To Solve It, Second Edition. New Jersey: Princeton University Press.

Rosen, Kenneth H. 1988. Discrete Mathematics and Its Applications. New York : Random House. 
Sagala, Syaiful. 2003. Konsep dan Makna Pembelajaran. Bandung : Penerbit Alfabeta.

Schoenfeld, AH. 1980. Heuristic in the Classroom, dalam Krulik S dan Reys RE (Ed) Problem Solving in School Mathematics. Virginia: NCTM.

Soedjadi, R, 2007, Masalah Kontekstual Sebagai Batu Sendi Matematika Sekolah, Pusat Sains dan Matematika Sekolah (PSMS) Unesa, Surabaya.

Soifer, Alexander. 2008. Mathematics as Problem Solving Second Editions. USA: Springer.

Solso, R.L.1987. Cognitive psychology, Allyn and Bacon, Inc., Boston.
Sunarto. 2001. Metodologi Penelitian Ilmuilmu Sosial dan Pendidikan. Surabaya: UNESA University Press.

Suparno, Paul. 2006. Filsafat Konstruktivisme dam Pendidikan. Yogyakarta: Percetakan Kanisius.

Watanabe, Ken. 2009. Problem Solving 101. Jakarta : Publishing One.

Yaumi, Muhammad. 2012. Pembelajaran Berbasis Multiple Intelligences. Jakarta : Dian Rakyat 
Tahun XI, No. 20, April 2015 